\title{
NONSTOICHIOMETRIC TIN OXIDE FILMS: STUDY BY X-ray DIFFRACTION, RAMAN SCATTERING AND ELECTRON PARAMAGNETIC RESONANCE
}

\author{
D.V. Adamchuk ${ }^{\text {a, }}$, V.K. Ksenevich ${ }^{\text {a }}$, N.A. Poklonski ${ }^{a}$, M. Navickas ${ }^{\text {b }}$, and J. Banys ${ }^{\text {b }}$ \\ ${ }^{a}$ Faculty of Physics, Belarusian State University, Nezalezhnastsi Ave. 4, 220030 Minsk, Belarus \\ ${ }^{\mathrm{b}}$ Faculty of Physics, Vilnius University, Sauletekio 9, 10222 Vilnius, Lithuania \\ Email: ksenevich@bsu.by
}

Received 18 October 2019; accepted 31 October 2019

\begin{abstract}
Nonstoichiometric $\mathrm{SnO} / \mathrm{SnO}_{2} / \mathrm{SnO}_{2-\delta}$ films were fabricated by DC magnetron sputtering and reactive $\mathrm{DC}$ magnetron sputtering of tin target with further 2-stage temperature annealing of synthesized materials. X-ray diffraction analysis, Raman spectroscopy and electron paramagnetic resonance (EPR) spectroscopy were employed to study the influence of oxygen content in the plasma during the sputtering process and the temperature of annealing on the stoichiometric and phase composition of synthesized films. It was found that the tin monoxide phase prevailed in the films fabricated by DC magnetron sputtering in the argon plasma followed by a 2-stage annealing process. Nanocrystalline films containing both tin monoxide and tin dioxide were synthesized when reactive magnetron sputtering with a small content of oxygen (of about 1 vol.\%) was used. The increase of oxygen content in the plasma to the value of about 2 vol.\% leads to the formation of amorphous films. The intensity of the Raman peaks inherent in $\mathrm{SnO}_{2}$ vibration modes was found to depend on the content of the tin monoxide phase in the films. This effect can be attributed to the dissipative transition of electronic excitation from tin monoxide to tin dioxide nanocrystallites.
\end{abstract}

Keywords: tin oxides, magnetron sputtering, X-ray diffraction, resonance Raman scattering, electron paramagnetic resonance

PACS: 68.55.Nq, 73.61.Le, 78.30.-j, 81.15.Cd

\section{Introduction}

The past several decades saw undiminished interest in studying properties of transparent conducting oxides (TCOs) because of a rare combination of electrical conductivity and optical transparency in these materials [1, 2]. Due to their excellent optical and electrical properties, TCOs are used for fabrication of various devices such as gas sensors, batteries, photocatalysts, flat-panel displays and solar cells [1, 2p. Besides these applications, transparent electrodes based on TCOs are important for optoelectronic devices, electrochemical and optical microscopy methods for cell biology and in photoelectrochemical microscopy [3]. For example, the transparent conducting oxides can be used as a new type of a transparent electrode, which enables photoswitchable electrochemistry and optical imaging [3]. One of more widely used metal oxide materials is tin oxide [2]. In spite of a number of experimental and theoretical investigations of tin oxides, a correspondence between their properties, on the one hand, and a crystalline structure and stoichiometric composition, on the other hand, is still debated. It has been known for more than hundred years that tin oxides can exist in different phases: $\mathrm{SnO}_{2}$ and $\mathrm{SnO}$, with oxidation states of +4 and +2 , respectively, and intermediate phases $\left(\mathrm{Sn}_{\mathrm{x}} \mathrm{O}_{y}\right.$, for example, $\mathrm{Sn}_{2} \mathrm{O}_{3}$ and $\mathrm{Sn}_{3} \mathrm{O}_{4}$ ) [2, 作. Among different tin oxide phases rutile-type $\mathrm{SnO}_{2}$ and tetragonal $\mathrm{SnO}$ attract great attention as multifunctional materials [5]. $\mathrm{SnO}_{2}$, 
the most stable of the tin oxide phases, is a wide band gap semiconductor $\left(E_{\mathrm{g}} \sim 3.6 \mathrm{eV}\right)$ and due to the intrinsic oxygen vacancies (OVs) has n-type conductivity [6]. Another type of point defects in $\mathrm{SnO}_{2}$ - tin interstitials - strongly reduce the formation energy of OVs acting thus as an additional factor of the nonstoichiometry of $\mathrm{SnO}_{2}$ [ [6]. Oxygen vacancies play a crucial role in electrical and optical properties, gas sensing mechanisms and the visible light photocatalitic activity of tin dioxide [6-10]. The first-principle calculations of $\mathrm{SnO}_{2}$ (110) surface demonstrate that the formation of different OVs can be controlled by asymmetric deformation [11]. The possibility of utilizing of nanostructured tin oxide $\mathrm{SnO}_{x}(1<x<2)$ as an optical sensor for the detection of nitroaromatic compounds based on the surface-enhanced Raman scattering effect was shown [12]. Therefore the identification and characterization of OVs are necessary for the fabrication of different devices based on nonstoichiometric tin oxide. Understanding of the aggregation mechanisms of oxygen vacancies and establishing of their influence on the electrical, optical and sensing properties of tin dioxide are important tasks for improving their performance in electronics, sensors, catalysis and other applications.

In contrast to tin dioxide, $\mathrm{SnO}$ is a p-type semiconductor due to the naturally formed $\mathrm{Sn}$ vacancies [13]. Formation of local $\mathrm{SnO}_{2} / \mathrm{SnO} \mathrm{p}-\mathrm{n}$ junctions can be used in some applications, for example, for fabrication of temperature sensors for transparent electronics [14] or gas sensors with enhanced sensitivity to $\mathrm{H}_{2}$ [13]. It should be noted that tin oxide can be easily transformed to tin dioxide using $\mathrm{SnO}$ oxidation or disproportionation reactions [15]. Therefore the phase transition $\mathrm{SnO} \rightarrow \mathrm{SnO}_{2}$ with a possible formation of intermediate tin oxide phases usually occur during fabrication of tin dioxide of various architecture by means of different methods: electron beam evaporation [16], spray pyrolysis [16, 17], sol-gel synthesis [12, 18], physical vapour deposition [17] and magnetron sputtering [19] followed by thermal annealing etc.

We proposed earlier the method of fabrication of tin oxide films with a different phase and stoichiometric composition with a possibility to synthesize samples with various parameters (electrical conductivity, band gap width, transmission coef- ficient in the visible and UV range of electromagnetic spectra) [20].

In this paper we present a study of the influence of synthesis parameters (oxygen content in argonoxygen plasma during reactive magnetron sputtering and temperature of post-deposition annealing) on the phase and stoichiometric composition of tin oxide films by means of X-ray diffraction, electron paramagnetic resonance and Raman scattering.

\section{Experimental details}

Nonstoichiometric $\mathrm{SnO} / \mathrm{SnO}_{2} / \mathrm{SnO}_{2-\delta}$ films were fabricated by DC magnetron sputtering in the argon plasma of tin onto glass substrates with a subsequent thermal oxidation of the formed layers in air [20]. In order to change the phase and stoichiometric composition, the electrical conductivity and transmission coefficient of the films, reactive magnetron sputtering in the argon-oxygen plasma was applied. The oxygen content during the deposition process was varied in a range of 0.4-2 vol.\%.

Besides that, the structural, electrical and optical properties of the fabricated tin oxide films of a mixed stoichiometric composition were controlled by temperature of annealing in air atmosphere. It was found that the 2-stage heat treatment process with the isothermal annealing at $200^{\circ} \mathrm{C}$ (near the melting temperature of $\mathrm{Sn}$ ) followed by high temperature annealing in the temperature interval $375-450^{\circ} \mathrm{C}$ provided a possibility to fabricate conductive and transparent tin oxide films [20].

The phase composition analysis was carried out using a Rigaku Ultima IV X-ray diffractometer in a parallel beam configuration using monochromatic $\mathrm{CuK} \alpha$ copper radiation $(0.15406 \mathrm{~nm})$ and a D/teX high-speed X-ray detector.

$\mathrm{X}$-band continuous-wave (CW) EPR spectra of $\mathrm{SnO} / \mathrm{SnO}_{2-\delta} / \mathrm{SnO}_{2}$ samples were measured at room temperature using a Bruker ELEXSYS E580 EPR spectrometer. The strength and frequency of the modulating field were set to $6 \mathrm{G}$ and $100 \mathrm{kHz}$, respectively. The sweep time of the EPR spectra was $120 \mathrm{~s}$.

The Raman spectra were recorded using a 3D confocal Raman spectral-analytical system $\mathrm{Na}$ nofinder $H E$ with two laser sources (with $\lambda=532$ and $473 \mathrm{~nm}$ ). Measurements were performed at 
room temperature in the backscattering configuration. The resolution of the spectrometer was $0.3 \mathrm{~cm}^{-1}$, the diameter of the beam spot was about $1 \mu \mathrm{m}$, and the input power was about $0.6 \mathrm{~mW}$.

\section{Results and discussion}

In order to determine the influence of the parameters of the technological process of tin oxide film fabrication on their phase composition the X-ray diffraction analysis was performed.

The XRD spectra of the $\mathrm{SnO} / \mathrm{SnO}_{2-\delta} / \mathrm{SnO}_{2}$ samples deposited in argon and argon-oxygen atmosphere and annealed in air at different temperature are shown in Fig. 1 .

Clear characteristic peaks that can be assigned to the (101), (110), (002), (200) and (112) planes of the tetragonal structure of the $\mathrm{SnO}$ phase were observed for the samples deposited in argon atmosphere and annealed at $300^{\circ} \mathrm{C}$ during the $2 \mathrm{nd}$ stage of the heat treatment procedure. The ther-

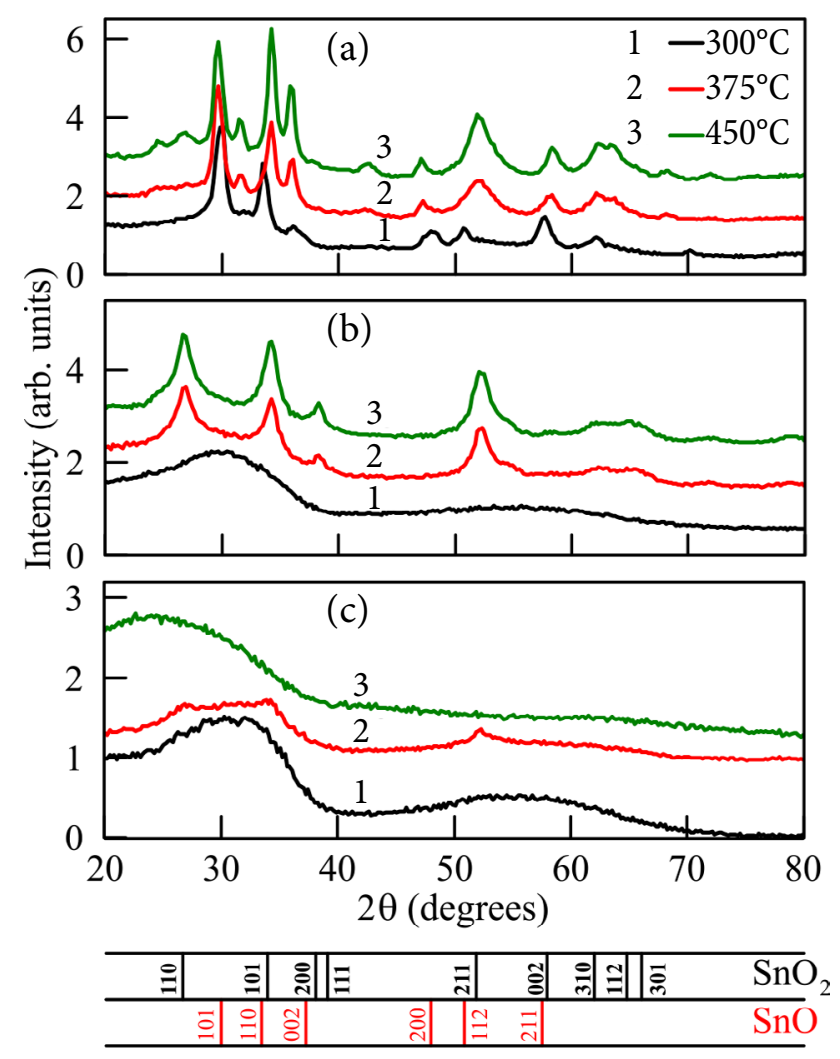

Fig. 1. XRD patterns of the $\mathrm{SnO} / \mathrm{SnO}_{2-\delta} / \mathrm{SnO}_{2}$ samples deposited in argon (a) and argon-oxygen (b, c) atmosphere with different oxygen content (vol. \%): 1 for (b), 2 for (c), and annealed in air at different temperature $\left({ }^{\circ} \mathrm{C}\right): 300$ for curve 1,375 for curve 2 , 450 for curve 3 . mal oxidation process of $\mathrm{SnO}$ to the $\mathrm{SnO}_{2}$ phase with a rutile structure was observed when the annealing temperature increased. As one can see from Fig. 1(a), for the samples annealed at 375 and $450^{\circ} \mathrm{C}$, besides characteristic peaks to the $\mathrm{SnO}$ phase, peaks that can be assigned to the (101), (211) and (002) planes of the rutile structure of $\mathrm{SnO}_{2}$ are clearly seen. The diffraction peaks that can be assigned to the Sn phase were observed for all samples deposited in argon atmosphere and annealed in the temperature range $300-450^{\circ} \mathrm{C}$ due to incomplete tin oxidation.

The average $\mathrm{SnO}_{2}$ crystallite size was estimated from the full width at half maximum (FWHM) intensity of the observed peaks using the DebyeScherrer equation in the form [21]

$$
D=K \lambda / \beta \cos \theta
$$

where $K$ is the shape factor which is usually equal to $0.9, \lambda$ is the radiation wavelength of $\mathrm{CuK} \alpha$ equal to $0.1542 \mathrm{~nm}, \theta$ is the Bragg diffraction angle, and $\beta$ is the full width at half maximum (FWHM) of the diffraction peak.

Estimation of the crystallite sizes for the films deposited in argon atmosphere gives values within the range $10-15 \mathrm{~nm}$. The rise of the crystallite sizes with the annealing temperature was unessential.

A wide band between 20 and $40^{\circ}$ without any distinctive characteristic peaks was observed on the diffraction spectra of the samples deposited by reactive DC sputtering (with oxygen content of around 1 vol.\%) and annealed at $300^{\circ} \mathrm{C}$ during the 2 nd stage of the heat treatment procedure assuming thus the formation of amorphous tin oxide films (Fig. 1(b)). Annealing at 375 and $450^{\circ} \mathrm{C}$ induces the formation of a polycrystalline $\mathrm{SnO}_{2}$ phase. The diffraction peaks observed around $26.6^{\circ}, 33.9^{\circ}$, $38^{\circ}$ and $52^{\circ}$ can be assigned to the (110), (101), (200) and (211) planes of the tetragonal rutile structure of $\mathrm{SnO}_{2}$. The estimation of the crystallite sizes for these films gives values of about $5-7 \mathrm{~nm}$.

When the oxygen content during reactive magnetron sputtering was increased to the value of around 2 vol.\%, only amorphous tin oxide films were synthesized at all annealing temperatures. As a result, only wide bands are visible in the diffraction spectra of these samples shown in Fig. 11(c).

Thus, as a result of the analysis of the XRD spectra of the $\mathrm{SnO} / \mathrm{SnO}_{2-\delta} / \mathrm{SnO}_{2}$ samples, we can 
conclude: i) tin oxide films of a variable stoichiometric composition with a predominant tin monoxide phase were fabricated by means of DC magnetron sputtering in the argon plasma followed by a 2 -stage annealing process; ii) reactive magnetron sputtering with a small content of oxygen (about 1 vol.\%) in the argon-oxygen plasma leads to the preferable formation of more thermodynamically stable tin dioxide nanocrystalline films with a tetragonal rutile-type crystalline structure; iii) increasing of oxygen content during the process of reactive magnetron sputtering up to the value of about 2 vol.\% induces the formation of amorhous tin oxide films after following a heat treatment procedure regardless of the annealing temperature. It should be noted that the crystalline structure of tin oxide films with a different stoichiometric composition can be improved by means of additional high-temperature annealing in vacuum or inert atmosphere [22].

Assuming that the oxygen vacancies at the interface between different tin oxide phases can work as paramagnetic trapping centres for electrons [23], we used EPR spectroscopy to look for the signal of paramagnetic oxygen vacancies $(\mathrm{OV})$ in the $\mathrm{SnO} / \mathrm{SnO}_{2-\delta} / \mathrm{SnO}_{2}$ samples. This method is known as a sensitive tool for the characterization of the paramagnetic centres on various oxide surfaces [24]. The X-band CW EPR spectra of the $\mathrm{SnO} / \mathrm{SnO}_{2-\delta} / \mathrm{SnO}_{2}$ samples deposited in argon

(a)

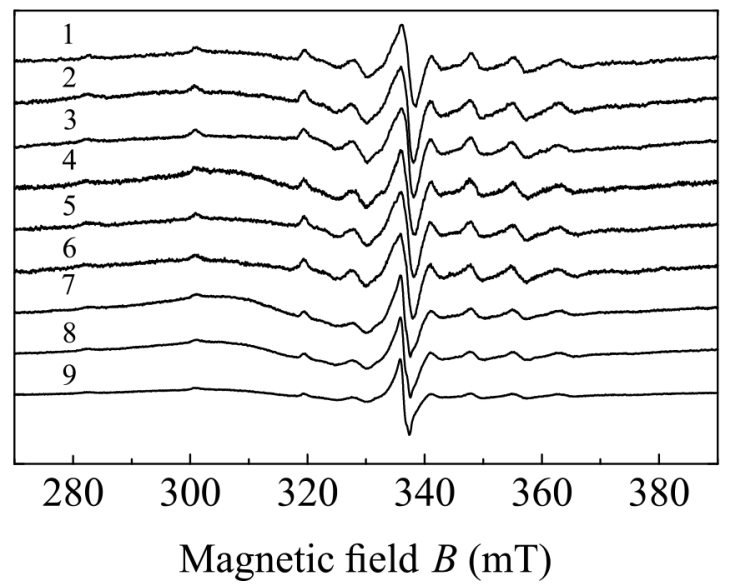

and argon-oxygen atmosphere and annealed in air at different temperatures are shown in Fig. 2. The obtained spectra are typical of the $\mathrm{Mn}^{2+}$ centres [25, 26]. In addition, each spectrum demonstrates an intense line at about $340 \mathrm{mT}$ ( $g$-factor 2). In order to study the origin of this central line, we performed experiments on the substrate without tin oxide. Figure 2(b) represents the EPR signal from the substrate (red online) and the signal from tin oxide on the substrate (black). The spectrum of the empty substrate demonstrates the same EPR signals as observed for the tin oxide samples indicating absence of the OV EPR signals from the tin oxide films.

For the additional characterization of a crystalline structure of the tin oxide samples with a different phase and stoichiometric composition Raman scattering spectroscopy was employed. This method is known as a sensitive tool for the characterization of the local structure, and the crystal surface area of solids and nanomaterials [27]. Information about crystallinity, orientation, composition, presence of structural defects, mechanical stress and doping of materials can be obtained from the Raman spectra. Characterization of tin oxide based structures by Raman spectroscopy is usually performed in order to get detailed information about their crystalline structure, phase and stoichiometric composition, presence of different types of oxygen vacancies etc. [28].

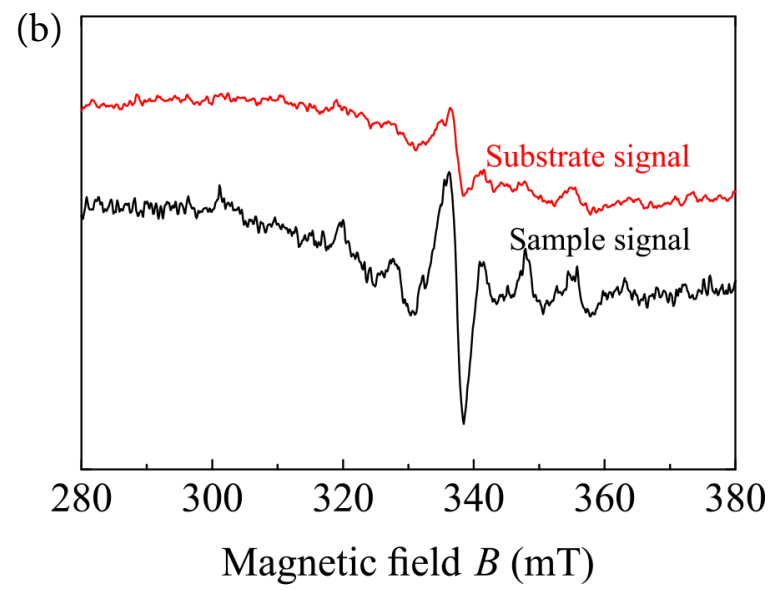

Fig. 2. (a) Averaged annealing temperature-dependent X-band CW EPR spectra of the $\mathrm{SnO} / \mathrm{SnO}_{2-\delta} /$ $\mathrm{SnO}_{2}$ samples deposited in argon (curves 1-3) and argon-oxygen atmosphere with oxygen content 1 vol.\% (curves 4-6) and 2 vol.\% (curves 7-9). Samples were annealed in air at temperature $300^{\circ} \mathrm{C}$ (curves 1, 4, 7), $375^{\circ} \mathrm{C}$ (curves 2, 5, 8) and $450^{\circ} \mathrm{C}$ (curves 3, 6, 9). (b) Comparison between the signals from the empty substrate and tin oxide film on the substrate. The $g$-factor of the central line $(\sim 340 \mathrm{mT})$ is about 2 . The signal near $300 \mathrm{mT}$ originates from $\mathrm{Fe}^{3+}$ centres. 
The Raman spectra of the samples synthesized with different content of oxygen during magnetron sputtering and various post-deposition annealing temperature registered with $\lambda=532$ and $473 \mathrm{~nm}$ laser excitation sources are shown in Figs. 3 and 4 , respectively.

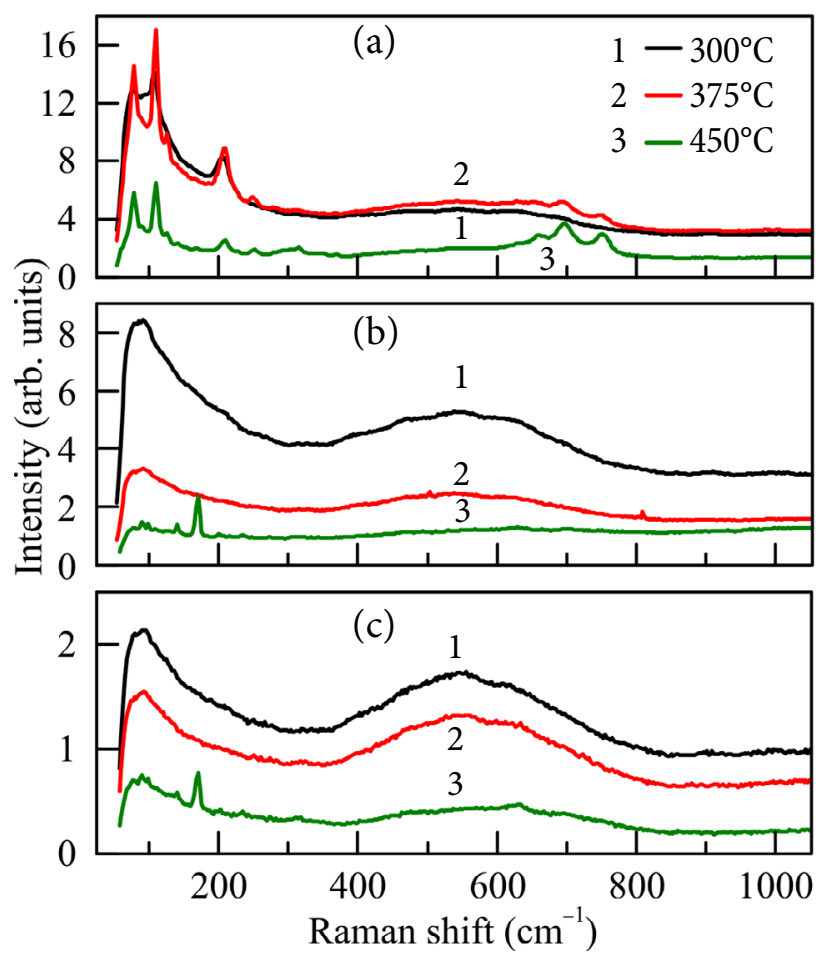

Fig. 3. Raman spectra measured with a $\lambda=532 \mathrm{~nm}$ laser source of the $\mathrm{SnO} / \mathrm{SnO}_{2-\delta} / \mathrm{SnO}_{2}$ samples deposited in argon (a) and argon-oxygen (b, c) atmosphere with different oxygen content (vol.\%): 1 for (b), 2 for (c), and annealed in air at different temperature $\left({ }^{\circ} \mathrm{C}\right): 300$ for curve 1, 375 for curve 2, 450 for curve 3 . The obtained spectra are neither normalized nor shifted along the $y$ axis.

For the samples deposited in argon atmosphere the peaks corresponding to the vibration modes inherent both in $\mathrm{SnO}$ and $\mathrm{SnO}_{2}$ crystalline structure were observed. For example, peaks at 111 and $750 \mathrm{~cm}^{-1}$ in the vicinity of the classical vibration modes $B_{1 g}$ and $B_{2 g}$ for single crystal $\mathrm{SnO}_{2}$ were observed for all annealing temperatures [2]. Besides that, for the samples deposited in argon atmosphere the peak at $692 \mathrm{~cm}^{-1}$ that can be attributed to the vibration mode $A_{2 \mu}$ of longitudinal optical phonons was detected [2]. The peak at $211 \mathrm{~cm}^{-1}$ corresponds to the $\mathrm{Sn}-\mathrm{O}$ vibrations in the tin oxide phase [29]. The intensity of this peak was de- creased for the samples annealed at $375^{\circ} \mathrm{C}$ and was unessential for the samples annealed at $450^{\circ} \mathrm{C}$. On the other hand, the amplitudes of inherent in $\mathrm{SnO}_{2}$ structure peaks near 692 and $750 \mathrm{~cm}^{-1}$ increased as the annealing temperature was raised. These modifications of the Raman spectra can be explained by oxidation of tin oxide and formation of the tin dioxide phase.

In contrast to the Raman spectra measured for the samples synthesized using magnetron sputtering in the argon plasma, no any distinctive peaks inherent either in $\mathrm{SnO}$ or in $\mathrm{SnO}_{2}$ crystalline structure were observed for the films fabricated by reactive magnetron sputtering. Only two broad bands in the range of about 50-200 and 400-700 $\mathrm{cm}^{-1}$ were detected for these samples. Existence of broad bands instead of narrow lines in Raman spectra is reported for nanocrystalline tin oxide samples and their attribution is closely connected with the grain size [30]. For example,

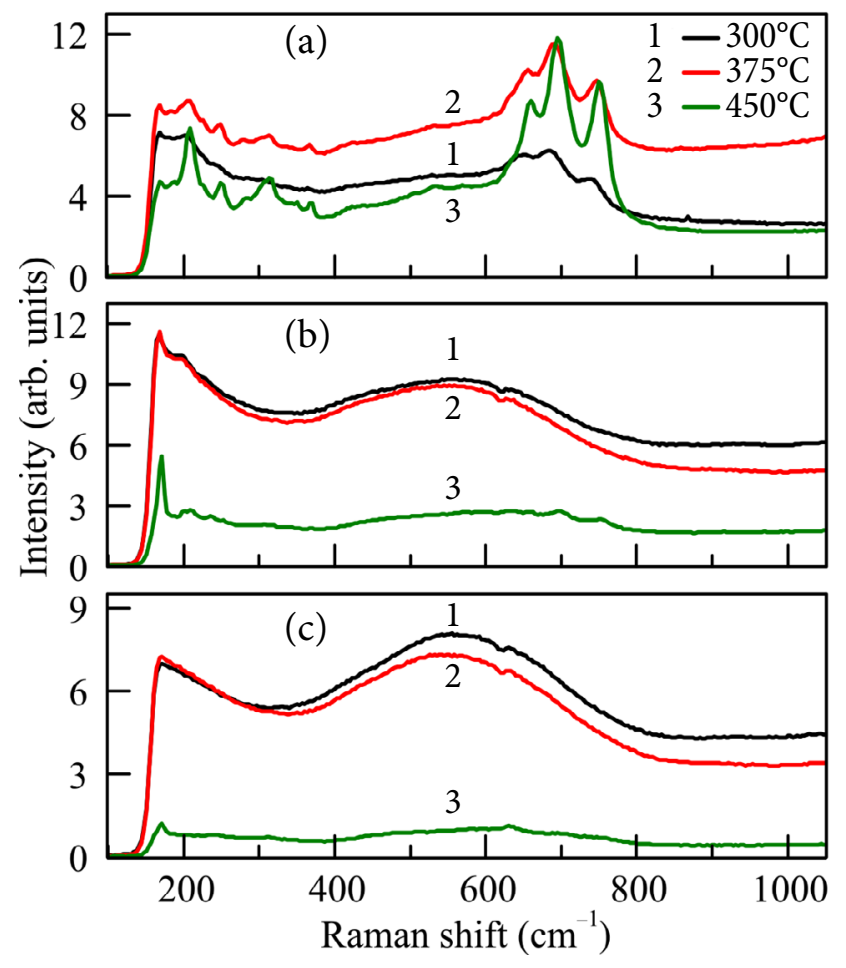

Fig. 4. Raman spectra measured with a $\lambda=473 \mathrm{~nm}$ laser source of the $\mathrm{SnO} / \mathrm{SnO}_{2-\delta} / \mathrm{SnO}_{2}$ samples deposited in argon (a) and argon-oxygen (b, c) atmosphere with different oxygen content (vol.\%): 1 for (b), 2 for (c), and annealed in air at different temperature $\left({ }^{\circ} \mathrm{C}\right): 300$ for curve 1, 375 for curve 2, 450 for curve 3 . The obtained spectra are neither normalized nor shifted along the $y$ axis. 
a broad band in the low-frequency region observed for powders with the particles smaller than $7 \mathrm{~nm}$ is attributed to acoustic modes associated with the vibration of an individual nanoparticle as a whole [30]. Broadening of the classical modes for monocrystalline tin dioxide and formation of a broad band in the high-frequency range is activated by surface disorder for nanosized grains [30]. Influence of the nanocrystaline sizes is not the only reason for modifications of the Raman spectra of tin dioxide samples in a high-frequency range. Shift and broadening of the classical vibrations modes, the appearance of additional peaks and shoulders on the Raman spectra of nonstoichiometric tin dioxide samples are attributed to the existence of different types (subbridging, bridging, in-plane) of oxygen vacancies [8]. The existence of the peaks near 140 and $170 \mathrm{~cm}^{-1}$ for the samples obtained by reactive magnetron sputtering can be explained by formation of phases $\mathrm{Sn}_{2} \mathrm{O}_{3}$ and $\mathrm{Sn}_{3} \mathrm{O}_{4}$ [ [4].

Differences in the intensity of the Raman spectra of the same samples measured at different excitation wavelengths can be explained by the resonant Raman scattering effect. It is known that in the case when the excitation wavelength coincides with the energy of electronic transition or photon absorption in the material, strong enhancement of the Raman active vibrational modes is observed [31]. The band gap width of our samples obtained by deposition in argon is in a range of $1.9-2.5 \mathrm{eV}$ in dependence on post-deposition annealing temperature. According to the X-ray diffraction analysis the tin oxide phase prevails in these samples (a band gap of tin monoxide is in a range of 2.5-3 eV [32]). Nonstoichiometric tin oxide films $\mathrm{SnO} / \mathrm{SnO}_{2-\delta} / \mathrm{SnO}_{2}$ obtained by reactive magnetron sputtering are characterized by a band gap in a range of 2.6-3.2 and 2.7-2.9 eV for the samples deposited in the argon-oxygen plasma with 1 and $2 \%$ oxygen content, respectively. The band gap for our samples was calculated from the results of the measurements of their adsorption spectra [20]. The deviation of the band gap from the value typical of monocrystalline tin dioxide is induced by nanocrystallinity and existence of defects (including oxygen vacancies) in our films. The dependence of the band gap width of the $\mathrm{SnO} / \mathrm{SnO}_{2-\delta} / \mathrm{SnO}_{2}$ samples on the synthesis conditions is presented in Table 1.
Table 1. Dependence of the band gap width of $\mathrm{SnO} /$ $\mathrm{SnO}_{2-\delta} / \mathrm{SnO}_{2}$ samples on the synthesis conditions.

\begin{tabular}{ccc}
\hline $\begin{array}{c}\text { Sputtering method } \\
\text { and oxygen content }\end{array}$ & $\begin{array}{c}\text { Second stage annealing } \\
\text { temperature, }{ }^{\circ} \mathrm{C}\end{array}$ & $\begin{array}{c}\text { Band } \\
\text { gap, eV }\end{array}$ \\
\hline $\begin{array}{c}\text { DC magnetron } \\
\text { sputtering in argon } \\
\text { plasma }\end{array}$ & 300 & 1.9 \\
\cline { 2 - 3 } & 375 & 2.4 \\
\hline \begin{tabular}{c} 
Reactive magne- \\
tron sputtering \\
(1 vol.\% oxygen \\
\cline { 2 - 3 } content)
\end{tabular} & 450 & 2.5 \\
\hline \begin{tabular}{c} 
Reactive magne- \\
tron sputtering \\
\cline { 2 - 3 }$(2$ vol.\% oxygen \\
content)
\end{tabular} & 300 & 2.6 \\
\hline
\end{tabular}

For the measurements of the Raman spectra of our films we used lasers with an excitation wavelength of $\lambda=532$ and $473 \mathrm{~nm}$ corresponding to the energy of 2.33 and $2.62 \mathrm{eV}$, respectively. Therefore the intensity of the Raman active modes for the samples obtained under the same synthesis conditions is higher in the case when we used a laser with a $\lambda=473 \mathrm{~nm}$ excitation wavelength. However, the samples characterized approximately by the same band gap have strongly different Raman spectra. For example, the films deposited in the argon plasma and annealed at $450^{\circ} \mathrm{C}$ have a band gap of $2.5 \mathrm{eV}$ and are characterized by the presence in the Raman spectra of vibration modes inherent in $\mathrm{SnO}_{2}$. Meanwhile, for the films deposited in the argon-oxygen plasma with $1 \%$ oxygen content plasma and annealed at $300^{\circ} \mathrm{C}$ with a band gap of $2.6 \mathrm{eV}$ we did not observe in the Raman spectra the vibration modes inherent in $\mathrm{SnO}_{2}$. According to the X-ray diffraction analysis both tin monoxide and tin dioxide phases are present in the films obtained by deposition in the argon plasma and annealed at $450^{\circ} \mathrm{C}$. The tin monoxide phase is absent for the films deposited in the argon-oxygen plasma with $1 \%$ oxygen content and annealed at $300^{\circ} \mathrm{C}$.

We can conclude that the presence of the tin monoxide phase in our samples is important for the fulfilment of resonant Raman scattering conditions. Increasing of the intensity peaks inherent in tin dioxide vibrational modes can be attributed to the dissipative transition of electronic 
excitation from tin monoxide atoms to tin dioxide atoms as an intermediate state in light scattering.

\section{Conclusions}

Characterization of tin oxide films with a different phase and stoichiometric composition was carried out using complementary methods: X-ray diffraction analysis, Raman spectroscopy and EPR spectroscopy. The possibility of using these techniques for the study of the influence of synthesis conditions (plasma composition and oxygen content in the argon-oxygen plasma during reactive magnetron sputtering, temperature of post-deposition annealing in air) on the structural properties and composition of nonstoichiometric tin oxide films was demonstrated. The room temperature X-band CW EPR measurements of the tin oxide films revealed no EPR signals from the OVs. A correlation between the X-ray diffraction patterns and Raman spectra was found for the samples with a different content of $\mathrm{SnO}$ and $\mathrm{SnO}_{2}$ phases. Enhancement of the intensity of the Raman peaks corresponding to the tin dioxide phase was observed in the samples containing both $\mathrm{SnO}$ and $\mathrm{SnO}_{2}$ due to the resonant Raman scattering in tin oxide and the dissipative transition of electronic excitation from tin monoxide atoms to tin dioxide atoms.

\section{Acknowledgements}

The work was supported by the State Committee on Science and Technology of the Republic of Belarus (Grant No. F19LITG-001), Research Council of Lithuania (Grant No. S-LB-19-5), Belarusian National Research Program 'Convergence-2020' (subprogram 'Integration', Grant No. 3.3.1), and by Program of EU H2020-MSCA-RISE-2015 (Grants No. 691010 HUNTER and No. 690968 NANOGUARD2Ar).

The authors are grateful to V.I. Shimanskij for the implementation of X-ray diffraction measurements, and A.V. Mazanik and O.V. Korolik for the recording of Raman spectra.

The authors acknowledge the Center of Spectroscopic Characterization of Materials and Electronic/Molecular Processes (SPECTROVERSUM, www.spectroversum.ff.vu.lt) at the Lithuanian National Center for Physical Sciences and Technology for providing spectroscopic equipment.

\section{References}

[1] H.L. Hartnagel, A.L. Dawar, A.K. Jain, and C. Jagadish, Semiconducting Transparent Thin Films (Institute of Physics Publishing, Bristol, UK, 1995).

[2] M. Batzill and U. Diebold, The surface and materials science of tin oxide, Prog. Surf. Sci. 79, 47-154 (2005).

[3] J. Lian, Y. Yang, W. Wang, S.G. Parker, V.R. Gonçales, R.D. Tilley, and J. Justin, Amorphous silicon on indium tin oxide: a transparent electrode for simultaneous light activated electrochemistry and optical microscopy, Chem. Commun. 55, 123-126 (2018).

[4] B. Eifert, M. Becker, C.T. Reindl, M. Giar, L.Zheng, A. Polity, Y. He, C. Heiliger, and P.J. Klar, Raman studies of the intermediate tin-oxide phase, Phys. Rev. Mater. 1, 014602-1-6 (2017).

[5] I.M. Tiginyanu, O. Lupan, V.V. Ursaki, L. Chow, and M. Enachi, in: Comprehensive Semiconductor Science and Technology, Vol. 3, eds. P. Bhattacharya, R. Fornari, H. Kamimura (Elsevier Science, Amsterdam, 2011) pp. 396-479.

[6] C. Kílíç and A. Zunger, Origins of coexistence of conductivity and transparency in $\mathrm{SnO}_{2}$, Phys. Rev. Lett. 88, 09550-1-4 (2002).

[7] K.G. Godinho, A. Walsh, and G.W. Watson, Energetic and electronic structure analysis of intrinsic defects in $\mathrm{SnO}_{2}$, J. Phys. Chem. C 113, 439-448 (2009).

[8] L.Z. Liu, T.H. Li, X.L. Wu, J.C. Shen, and P.K. Chu, Identification of oxygen vacancy types from Raman spectra of $\mathrm{SnO}_{2}$ nanocrystals, J. Raman Spectrosc. 43, 1423-1426 (2012).

[9] M. Epifani, J.D. Prades, E. Comini, E. Pellicer, M. Avella, P. Siciliano, G. Faglia, A. Cirera, R. Scotti, F. Morazzoni, and J.R. Morante, The role of surface oxygen vacancies in the $\mathrm{NO}_{2}$ sensing properties of $\mathrm{SnO}_{2}$ nanocrystals, J. Phys. Chem. C 112, 19540-19546 (2008).

[10]Y. Yang, Y. Wang, and S. Yin, Oxygen vacancies confined in $\mathrm{SnO}_{2}$ nanoparticles for desirable electronic structure and enhanced visible light photocatalytic activity, Appl. Surf. Sci. 420, 399-406 (2017). 
[11]Z.H. Zhou, Y.M. Min, X.X. Liu, J.Q. Ding, J.H. Guo, F.R. Hu, and L.Z. Liu, Regulation of oxygen vacancy types on $\mathrm{SnO}_{2}$ (110) surface by external strain, AIP Adv. 6, 055102-1-7 (2016).

[12]K. Vijayarangamuthu and S. Rath, Nanostructured tin oxide as a surface-enhanced Raman scattering substrate for the detection of nitroaromatic compounds, Int. J. Appl. Ceram. Technol. 12, 790-794 (2015).

[13]A. Shanmugasundaram, P. Basak, L. Satyanarayana, and S.V. Manorama, Hierarchical $\mathrm{SnO} / \mathrm{SnO}_{2}$ nanocomposites: formation of in-situ $p-n$ junctions and enhanced $\mathrm{H}_{2}$ sensing, Sens. Actuators B Chem. 185, 265-273 (2013).

[14]Z. Wang, P.K. Nayak, A. Albar, N. Wei, U. Schwingenschlögl, and H.N. Alshareef, Transparent $\mathrm{SnO}-\mathrm{SnO}_{2}$ p- $\mathrm{n}$ junction diodes for electronic and sensing applications, Adv. Mater. Interfaces 2(18), 1500374-1-7 (2015).

[15]C.M. Campo, J.E. Rodríguez, and A.E. Ramírez, Thermal behaviour of romarchite phase $\mathrm{SnO}$ in different atmospheres: a hypothesis about the phase transformation, Heliyon 2, e00112-113 (2016).

[16]K.S. Shamala, L.C.S. Murthy, and K. Narasimha Rao, Studies on tin oxide films prepared by electron beam evaporation and spray pyrolysis methods, Bull. Mater. Sci. 27(3), 295-301 (2004).

[17]S.H. Park, Y.C. Son, W.S. Willis, S.L. Suib, and K.E. Creasy, Tin oxide films made by physical vapor deposition-thermal oxidation and spray pyrolysis, Chem. Mater. 10(9), 2389-2398 (1998).

[18]M. Marikkannan, V. Vishnukanthan, A. Vijayshankar, J. Mayandi, and J.M. Pearce, A novel synthesis of tin oxide thin films by the sol-gel process for optoelectronic applications, AIP Adv. 5, 027122-1-8 (2015).

[19]V.K. Ksenevich, D.V. Adamchuk, V.B. Odzhaev, and P. Zhukowski, Fabrication and characterization of transparent tin dioxide films with variable stoichiometric composition, Acta Phys. Pol. A 128, 861-863 (2015).

[20]D.V. Adamchuck and V.K. Ksenevich, Control of electrical and optical parameters of humidity sensors active elements based on tin oxides films with variable composition, Dev. Meth. Meas. 10(2), 138-150 (2019) [in Russian].

[21]P. Boroojerdian, Structural and optical study of SnO nanoparticles synthesized using microwaveassisted hydrothermal route, Int. J. Nanosci. Nanotechnol. 9(2), 95-100 (2013).

[22]D.V. Adamchuck, V.K. Ksenevich, N.I. Gorbachuk, and V.I. Shimanskij, Impedance spectroscopy of polycrystalline tin dioxide films, Dev. Meth. Meas. 7(3), 312-321 (2016) [in Russian].

[23]M. Ivanovskaya, E. Ovodok, and V. Golovanov, The nature of paramagnetic defects in tin (IV) oxide, Chem. Phys. 457, 98-105 (2015).

[24]D.M. Murphy, in: Metal Oxide Catalysis, Ch. 1, eds. S.D. Jackson and J.S.J. Hargreaves (WileyVCH Verlag GmbH \& Co. KGaA, Weinheim, 2008) pp. 1-50.

[25]V. Jain and G. Lehmann, Electron paramagnetic resonance of $\mathrm{Mn}^{2+}$ in orthorhombic and higher symmetry crystals, Phys. Status Solidi B 159, 495 (1990).

[26]F. Murzakhanov, G. Mamin, A. Voloshin, E. Klimashina, V. Putlyaev, V. Doronin, S. Bakhteev, R. Yusupov, M. Gafurov, and S. Orlinskii, Conventional electron paramagnetic resonance of $\mathrm{Mn}^{2+}$ in synthetic hydroxyapatite at different concentrations of the doped manganese, IOP Conf. Ser. Earth Environ. Sci. 155, 012006 (2018).

[27]D.J. Gardiner, Practical Raman Spectroscopy (Springer-Verlag, 1989).

[28]M.N. Rumyantseva, A.M. Gaskov, N. Rosman, T. Pagnier, and J.R. Morante, Raman surface vibration modes in nanocrystalline $\mathrm{SnO}_{2}$ : Correlation with gas sensor performances, Chem. Mater. 17, 893-901 (2005).

[29]E.L. Peltzer y Blanka, A. Svane, N.E. Christensen, C.O. Rodriguez, O.M. Cappannini, and M.S. Moreno, Calculated static and dynamic properties of $\beta$-Sn and Sn-O compounds, Phys. Rev. B 48, 15712-15718 (1993).

[30]A. Diéguez, A. Romano-Rodriguez, A. Vilà, and J.R. Morante, The complete Raman spectrum of nanometric $\mathrm{SnO}_{2}$ particles, J. Appl. Phys. 90, 1550-1557 (2001).

[31]D. Tuschel, Exploring resonance Raman spectroscopy, Spectroscopy 33, 12-19 (2018). 
[32]M. Alaf, M. Guler, D. Gultekin, and H. Akbulut, Effects of substrate temperature on structural properties of tin oxide films produced by plasma oxidation after thermal evaporation, Acta Phys.

Pol. A 123, 326-329 (2013).

\title{
NESTECHIOMETRINĖS ALAVO OKSIDO PLE்VELĖS: RENTGENO SPINDULIŲ DIFRAKCIJOS, RAMANO SKLAIDOS IR ELEKTRONŲ PARAMAGNETINIO REZONANSO TYRIMAI
}

\author{
D.V. Adamchuk a, , , V.K. Ksenevich ${ }^{\text {a }}$, N.A. Poklonski ${ }^{a}$, M. Navickas ${ }^{\text {b }}$, J. Banys ${ }^{\text {b }}$ \\ a Baltarusijos valstybinio universiteto Fizikos fakultetas, Minskas, Baltarusija \\ ${ }^{\mathrm{b}}$ Vilniaus universiteto Fizikos fakultetas, Vilnius, Lietuva
}

\section{Santrauka}

Nestechiometrinès $\mathrm{SnO} / \mathrm{SnO}_{2} / \mathrm{SnO}_{2-\delta}$ plèvelès buvo gaminamos nuolatinès srovès (DC) magnetroninio ir reaktyviojo DC magnetroninio dulkinimo būdu, panaudojant alavo bandinị bei gautą medžiagą kaitinant dvejomis pakopomis. Siekiant ištirti deguonies kiekio plazmoje, naudotoje magnetroninio dulkinimo metu, bei kaitinimo temperatūros ịtaką bandinių stecheometrinei ir fazinei struktūrai, buvo panaudota Rentgeno struktūrinè analizè, Ramano ir elektronų paramagnetinio rezonanso (EPR) spektroskopijos. Nustatyta, kad bandiniuose, gautuose nuolatinès srovès magnetroninio dulkinimo būdu argono plazmoje, panaudojant dviejų pakopų kaitinimą dominuoja alavo monoksido fazè. Nanokristalinès plèvelès, savyje turinčios tiek alavo monoksido, tiek alavo dioksido, buvo susintetintos reaktyviuoju nuolatinès srovès dulkinimo būdu, panaudojant mažą kiekị deguonies (1 vol\%). Deguonies padidejjimas plazmoje iki $\sim 2$ vol\% skatina amorfinių plèvelių formavimąsi. Nustatyta, kad Ramano spektrų intensyvumai, nusakantys $\mathrm{SnO}_{2}$ vibracines modas, priklauso nuo alavo monoksido kiekio plèvelèse. Šis reiškinys gali būti siejamas su elektroninio sužadinimo sukeltu disipaciniu virsmu iš alavo monoksido į alavo dioksido nanokristalitus. 